\title{
VALIDASI LAMANYA WAKTU PENGERINGAN UNTUK PENETAPAN KADAR AIR PAKAN METODE OVEN DALAM PRAKTIKUM ANALISIS PROKSIMAT
}

\section{Validation of Drying Time for Determining The Feed Moisture Content Using Oven Method in The Proximate Analysis Practicum}

\author{
Bagus Djuni Ahadi ${ }^{1}$ dan Mohammad Yasir Effendi ${ }^{2}$ \\ 1 Jurusan Peternakan, Politeknik Negeri Jember \\ ${ }^{2}$ Jurusan Teknologi Pertanian, Politeknik Negeri Jember \\ Email: bagus_djuni@polije.co.id
}

\begin{abstract}
INTISARI
Tujuan penelitian adalah menentukan lama waktu pengeringan untuk mencapai berat konstan dalam proses penetapan kadar air pakan dengan metode oven dalam praktikum analisis proksimat. Perlakuan meliputi pengeringan dengan suhu $105^{\circ} \mathrm{C}$ (lama pengeringan $4,5,6,7,8$ jam dan atau sampai tercapai berat konstan) dan suhu $110^{\circ} \mathrm{C}$ (lama pengeringan 2, 3, 4, 5, 6 jam dan atau sampai tercapai berat konstan) terhadap 5 macam sampel yang mempunyai kadar air simpan $\leq 14 \%$, meliputi: BR1, konsentrat broiler (KBr), jagung giling, bekatul, dan bungkil kedelai. Metode analisis data adalah rerata dari perlakuan yang diulang sebanyak 5 kali dari 5 macam sampel. Hasil penelitian ini disimpulkan bahwa untuk menetapkan kadar air dengan metode oven pada bahan pakan dan pakan yang mempunyai kadar air simpan $(\leq 14 \%)$ membutuhkan waktu lama pengeringan optimum 6 jam pada suhu $105^{\circ} \mathrm{C}$ dan 4 jam pada suhu $110^{\circ} \mathrm{C}$.
\end{abstract}

Kata kunci: Kadar Air, Metode Oven, Proksimat

\begin{abstract}
The purpose of the study was to determine the length of drying time to achieve constant weight in the process of determining the water content of the feed by the oven method in the proximate analysis. This treatment were drying with $105^{\circ} \mathrm{C}$ (drying time 4, 5, 6, 7, 8 hours and or until a constant weight was reached) and $110^{\circ} \mathrm{C}$ (drying time 2, 3, 4, 5, 6 hours and or until a constant weight was reached) for 5 types of samples that had water content of $\leq 14 \%$, including: BR1, broiler concentrate (KBr), cracked corn, rice bran and soybean meal. The data analysis was the average of treatments that repeated 5 times on 5 sample types. The results of this study concluded that to determine the water content by the oven method on feed and feed ingredients that had water content $\leq 14 \%$ required an optimum drying time for 6 hours at $105^{\circ} \mathrm{C}$ and 4 hours at $110^{\circ} \mathrm{C}$.
\end{abstract}

Keywords: Water Content, Oven Method, Proximate

\section{PENDAHULUAN}

Kurikulum berbasis kompetensi di perguruan tinggi melalui SK Mendiknas No. 045/U/2002, terjadi perubahan paradigma dalam proses pembelajaran dari berbasis teori menjadi ke arah praktik. Politeknik Negeri Jember merupakan salah satu perguruan tinggi vokasi yang menerapkan sistem pembelajaran berbasis kompetensi.
Buku Kerja Praktik Mahasiswa (BKPM) merupakan buku yang dibuat dalam rangka mendukung sistem pembelajaran berbasis kompetensi yang berisi pedoman dalam melaksanakan kegiatan praktikum.

Analisis proksimat pakan ternak merupakan salah satu kegiatan praktikum yang terdapat di dalam Buku Kerja Praktik Mahasiswa pada Jurusan Peternakan, Politeknik Negeri Jember. Analisis proksimat 
merupakan dasar analisis kimia dari pakan, jaringan tubuh, feses ataupun ekskreta yang diantaranya berguna untuk menentukan estimasi dari nilai kecernaan dan manfaat pakan, juga untuk menentukan kadar standar zat gizi.

Penetapan kadar air pakan metode oven atau termogravimetri merupakan salah satu bagian di dalam kegiatan analisis proksimat. Analisis proksimat merupakan sistem yang digunakan untuk mengetahui 6 macam fraksi, yaitu: air, abu, protein kasar, lemak kasar, serat kasar, dan bahan ekstrak tanpa nitrogen (BETN). Khusus untuk BETN nilainya dapat dicari dengan perhitungan $100 \%$ dikurangi jumlah dari kelima fraksi yang lain (Tillman et al., 1998).

Kadar air bahan pakan merupakan pengukuran jumlah air total yang terkandung dalam bahan pakan, tanpa memperlihatkan kondisi atau derajat keterikatan air. Kadar air bahan pakan dapat diukur dengan berbagai cara. Metode umum yang dilakukan adalah pengeringan dengan oven. Metode ini digunakan untuk seluruh produk pakan dan makanan, kecuali jika pada produk tersebut mengandung komponen-komponen yang mudah menguap pada pengeringan $100^{\circ} \mathrm{C}$ (Soelistyono, 1976). Kandungan air bahan pakan perlu diketahui terutama untuk menentukan persentase zat-zat gizi secara keseluruhan. Jumlah kadar air yang terdapat di dalam pakan sangat berpengaruh terhadap susunan persentase zat-zat gizi secara keseluruhan. Kandungan air dari suatu bahan pakan menentukan berat keringnya.

Cara mendapatkan persentase kadar air yakni sampel bahan pakan ditimbang, diletakkan dalam cawan khusus dan dipanaskan dalam oven 105 sampai dengan $110^{\circ} \mathrm{C}$. Hasil analisis ini akan diperoleh kadar bahan kering (bahan yang sudah bebas air) dengan cara $100 \%$ dikurangi dengan kadar air (Tim Laboratorium Ilmu dan Teknologi Pakan Fapet IPB, 2012). Pengeringan dihentikan hingga tercapai berat sampel menjadi konstan. Tim Pengampu Praktikum Bahan
Pakan Ternak Unggas Politeknik Negeri Jember (2016) menyatakan bahwa penetapan kadar air pakan menggunakan oven dengan suhu 105 sampai dengan $110^{\circ} \mathrm{C}$ selama 8 jam. Anggorodi (2005) menyatakan bahwa penentuan kadar air dengan cara dikeringkan di dalam alat pengering dengan suhu $105^{\circ} \mathrm{C}$ selama 4 sampai dengan 6 jam. Winarno (2005) menyatakan penetapan kadar air dilakukan dengan mengeringkan bahan dalam oven suhu $110^{\circ} \mathrm{C}$ selama 3 jam atau sampai berat konstan. Berdasarkan hal tersebut, maka perlu dilakukan penelitian validasi lama waktu pengeringan yang dibutuhkan sampai kadar air konstan menggunakan metode oven pada suhu 105 sampai dengan $110^{\circ} \mathrm{C}$. Tujuan penelitian ini adalah untuk mengetahui lama waktu pengeringan yang optimum hingga tercapainya kadar air konstan dalam penetapan kadar air bahan pakan dengan metode oven yang akan digunakan pada praktikum analisis proksimat.

\section{MATERI DAN METODE}

Penelitian ini dilaksanakan di Laboratorium Teknologi Pakan Ternak, Jurusan Peternakan, Politeknik Negeri Jember.

\section{Materi Penelitian}

Peralatan yang digunakan dalam penelitian meliputi: neraca analitik, oven pengering (drying oven), vochdoos (cawan porselen dan tutup), desikator, tang penjepit, sendok analisis stainless, dan sample mill. Bahan yang digunakan dalam penelitian adalah pakan maupun bahan pakan dengan kadar air simpan $\leq 14 \%$ sesuai dengan pendapat Saenab et al. (2010) yang menyatakan bahwa industri pakan ternak membutuhkan bahan pakan yang berkadar air rendah yaitu dibawah $15 \%$, dan hal tersebut berhubungan dengan daya simpan. Bahanbahan yang digunakan meliputi: pakan ayam pedaging (BR1), konsentrat broiler (KBr), jagung giling, bekatul, bungkil kedelai, dan silica gel. 


\section{Metode Penelitian}

Penelitian ini terdiri dari 2 perlakuan suhu pengeringan yaitu: perlakuan dengan suhu $105^{\circ} \mathrm{C}$ (lama waktu pengeringan $4,5,6$, 7, 8 jam dan atau sampai tercapai berat sampel konstan) dan perlakuan dengan suhu $110^{\circ} \mathrm{C}$ (lama waktu pengeringan $2,3,4,5,6$ jam dan atau sampai tercapai berat sampel konstan). Setiap waktu perlakuan terdiri dari 5 ulangan, masing-masing ulangan terdiri dari 1 sampel bahan pakan.

Pelaksanaan penelitian dimulai dengan menimbang vochdoos dalam kondisi tertutup (X), kemudian sampel bahan ditimbang dalam vochdoos tersebut $\pm 2 \mathrm{~g}(\mathrm{Y})$. Setelah itu dikeringkan dalam oven pada suhu $105^{\circ} \mathrm{C}$ dan $110^{\circ} \mathrm{C}$, tutup dilepas dengan lama waktu sesuai masing-masing perlakuan. Setelah waktu pengeringan tercapai, vochdoos berisi sampel dimasukkan dalam desikator selama 1 jam, kemudian ditimbang kembali dalam kondisi tertutup (Z), dan dilakukan perhitungan kadar air (\%). Prosedur yang sama juga dilakukan pada sampel bahan pakan yang lain. Hasil penelitian ini dianalisis secara deskriptif menurut Suyanto (2011).

\section{HASIL DAN PEMBAHASAN}

Hasil pengamatan menunjukkan bahwa rerata kadar air pakan dengan perlakuan suhu $105^{\circ} \mathrm{C}$ dan $110^{\circ} \mathrm{C}$ dengan lama pengeringan yang berbeda menunjukkan hasil kadar air yang berbeda. Nilai persentase kadar air (KA) pakan metode oven suhu $105^{\circ} \mathrm{C}$ disajikan seperti pada Tabel 1 .

Tabel 1. Rerata Persentase Kadar Air (KA) Pakan Metode Oven Suhu $105^{\circ} \mathrm{C}$

\begin{tabular}{|c|c|c|c|c|c|c|c|}
\hline \multirow{2}{*}{$\begin{array}{c}\text { Bahan } \\
(\%)\end{array}$} & \multicolumn{5}{|c|}{ Lama Waktu Pengeringan (Jam) } & \multirow{2}{*}{$\begin{array}{c}\text { Rerata KA } \\
\text { Konstan }\end{array}$} & \multirow{2}{*}{$\begin{array}{c}\text { Standar } \\
\text { Deviasi KA } \\
\text { Konstan }\end{array}$} \\
\hline & 4 & 5 & 6 & 7 & 8 & & \\
\hline BR1 & 9,78 & 9,87 & $10,08^{*}$ & $10,09^{*}$ & $10,09^{*}$ & $10,09^{*}$ & $0,0025^{*}$ \\
\hline $\mathrm{KBr}$ & 6,46 & $6,78^{*}$ & $6,77^{*}$ & $6,78^{*}$ & $6,77^{*}$ & $6,77^{*}$ & $0,0034^{*}$ \\
\hline Jagung Giling & 10,22 & 10,53 & $10,65^{*}$ & $10,66^{*}$ & $10,67^{*}$ & $10,66^{*}$ & $0,0045^{*}$ \\
\hline Bekatul & 8,29 & 8,61 & $8,90 *$ & $8,89 *$ & $8,90^{*}$ & $8,90^{*}$ & $0,0056^{*}$ \\
\hline Bungkil Kedelai & 10,33 & 10,41 & $10,85^{*}$ & $10,85^{*}$ & $10,86^{*}$ & $10,85^{*}$ & $0,0034^{*}$ \\
\hline
\end{tabular}

*Berat konstan

Validasi adalah suatu tindakan yang membuktikan bahwa suatu proses dapat memberikan hasil yang sesuai dengan syarat yang telah ditetapkan dan terdokumentasi dengan baik. BSP (2014) menyatakan bahwa validasi adalah tindakan konfirmasi melalui pengujian dan penyediaan bukti objektif bahwa persyaratan tertentu untuk suatu maksud tertentu dipenuhi.

Prinsip penetapan kadar air dengan metode oven atau termogravimetri yaitu menguapkan air dalam bahan dengan cara pengeringan serta penimbangan bahan sampai berat konstan artinya semua air sudah diuapkan semaksimal mungkin.

Bahan yang telah mengalami proses pengeringan lebih bersifat higroskopis dari pada bahan asalnya. Oleh karena itu, selama pendinginan sebelum penimbangan, sampel bahan ditempatkan dalam desikator yang diberi silika gel sebagai zat penyerap. Sudarmadji et al. (2007) menyatakan bahwa silika gel yang digunakan sering diberi warna sebagai indikator yang menunjukkan jenuh atau tidaknya kandungan air sampel. Lama pengeringan menggunakan suhu $110^{\circ} \mathrm{C}$ disajikan pada Tabel 2 .

Hasil penelitian pada perlakuan suhu $105^{\circ} \mathrm{C}$ (lama waktu pengeringan $4,5,6,7$, dan 8 jam) dan perlakuan suhu $110^{\circ} \mathrm{C}$ (lama waktu pengeringan $2,3,4,5$, dan 6 jam) menunjukkan bahwa kadar air konstan sampel yaitu BR1, KBr, jagung giling, bekatul, dan bungkil kedelai dengan metode oven tercapai pada lama waktu pengeringan tertentu. 
Rerata persentase kadar air BR1 dengan lama pengeringan $4 \mathrm{jam}$, suhu $105^{\circ} \mathrm{C}$ adalah 9,78\%. Lama pengeringan 5, 6, 7, dan 8 jam masing-masing diperoleh kadar air 9,87\%; 10,08\%; 10,09\%; dan 10,09\%. Rerata persentase kadar air jagung giling dengan lama pengeringan 4 jam suhu $105^{\circ} \mathrm{C}$ adalah $10,21 \%$, dan lama pengeringan $5,6,7$, dan 8 jam adalah 10,53\%; 10,66\%; 10,66\%; dan $10,67 \%$.

Pengeringan selama 4, 5, 6, 7, dan 8 jam dengan suhu $105^{\circ} \mathrm{C}$ masing-masing tercapai rerata persentase kadar air bekatul adalah 8,29\%; 8,60\%; 8,90\%; 8,90\%; dan 8,90\%. Lama pengeringan selama 4, 5, 6, 7, dan 8 jam dengan suhu $105^{\circ} \mathrm{C}$ tercapai rerata persentase kadar air pada bungkil kedelai (BKK) masingmasing adalah 10,33\%; 10,41\%; 10,85\%; 10,85\%; dan $10,86 \%$.
Pengeringan suhu $105^{\circ} \mathrm{C}$ sampel sampai kadar air konstan tercapai pada pengeringan minimal 6 jam. Hal ini ditunjukan dengan pengeringan selanjutnya selama 7 sampai 8 jam memberikan rerata persentase kadar air yang tidak berbeda jauh dengan pengeringan selama 6 jam, yaitu nilai rerata BR1 sebesar $10,09 \%$; jagung giling sebesar 10,66\%; bekatul sebesar 8,90\%; dan bungkil kedelai sebesar $10,85 \%$ dengan nilai standar deviasi masing-masing dari bahan tersebut kurang dari $1(\mathrm{SD}<1)$, dimana nilai akurasinya lebih dari 99\%. Hal ini menunjukkan bahwa penyebaran nilai-nilai tersebut sangat kecil dan mendekati nilai reratanya. Standar deviasi menggambarkan sebaran nilai-nilai sampel. Semakin kecil nilai standar deviasi maka nilai-nilai pada sampel data cenderung mendekati nilai reratanya.

Tabel 2. Rerata Persentase Kadar Air (KA) Pakan Metode Oven Suhu $110^{\circ} \mathrm{C}$

\begin{tabular}{|c|c|c|c|c|c|c|c|}
\hline \multirow{2}{*}{$\begin{array}{c}\text { Bahan } \\
(\%)\end{array}$} & \multicolumn{5}{|c|}{ Lama Waktu Pengeringan (Jam) } & \multirow{2}{*}{$\begin{array}{c}\text { Rerata KA } \\
\text { Konstan }\end{array}$} & \multirow{2}{*}{$\begin{array}{l}\text { Standar } \\
\text { Deviasi KA } \\
\text { Konstan }\end{array}$} \\
\hline & 2 & 3 & 4 & 5 & 6 & & \\
\hline BR1 & 9,52 & 10,00 & $10,08^{*}$ & $10,09 *$ & $10,08^{*}$ & $10,08^{*}$ & $0,0021^{*}$ \\
\hline $\mathrm{KBr}$ & 6,38 & 6,59 & $6,77^{*}$ & $6,78^{*}$ & $6,77^{*}$ & $6,78^{*}$ & $0,0036^{*}$ \\
\hline Jagung Giling & 9,48 & 10,23 & $10,66^{*}$ & $10,66^{*}$ & $10,66^{*}$ & $10,66^{*}$ & $0,0021 *$ \\
\hline Bekatul & 7,74 & 8,34 & $8,90 *$ & $8,90 *$ & $8,91^{*}$ & $8,90^{*}$ & $0,0035^{*}$ \\
\hline Bungkil kedelai & 10,26 & 10,37 & $10,85^{*}$ & $10,85^{*}$ & $10,86^{*}$ & $10,86^{*}$ & $0,0045^{*}$ \\
\hline
\end{tabular}

*Berat konstan

Pengeringan sampel pakan $\mathrm{KBr}$ selama $4,5,6,7$, dan 8 jam dengan suhu $105^{\circ} \mathrm{C}$ menghasilkan rerata kadar air sebesar 6,46\%; $6,77 \% ; 6,77 \% ; 6,78 \%$; dan 6,77\%. Rerata kadar air konstan tercapai pada lama pengeringan minimal 5 jam. Waktu tersebut lebih cepat dibandingkan pada waktu pengeringan BR1, jagung giling, bekatul, dan bungkil kedelai. Hal ini diduga kandungan kadar air $\mathrm{KBr}$ lebih kecil. Kandungan air awal bahan merupakan sifat bahan yang menjadi salah satu faktor yang mempengaruhi lama waktu pengeringan (Fellow, 2001).

Rerata kadar air konstan suhu $105^{\circ} \mathrm{C}$ sampel $\mathrm{KBr}$ adalah $6,77 \%$ dengan nilai standar deviasi $0,0033(\mathrm{SD}<1)$, akurasinya 99\%, sama dengan BR1, jagung giling, bekatul dan bungkil kedelai. Hal ini menunjukkan penyebaran nilai mendekati rerata persentase kadar air konstan.

Rerata persentase kadar air konstan tercapai dengan lama pengeringan 6 jam pada sampel bahan BR1, jagung giling, bekatul, dan bungkil kedelai, sedangkan rerata kadar air konstan pada $\mathrm{KBr}$ tercapai pada lama pengeringan 5 jam. Hal tersebut sesuai dengan pendapat Anggorodi (2005) yang menyatakan bahwa penentuan kadar air dengan cara dikeringkan di dalam alat pengering dengan suhu $105^{\circ} \mathrm{C}$ selama 4 sampai dengan 6 jam.

Rerata persentase kadar air BR1 pada suhu $110^{\circ} \mathrm{C}$ dengan lama pengeringan 2 jam adalah 9,52\%. Lama pengeringan 3, 4, 5, dan 6 
jam masing-masing diperoleh kadar air 10,01\%; 10,08\%; 10,09\%; dan 10,08\%. Rerata persentase kadar air $\mathrm{KBr}$ pada suhu $110^{\circ} \mathrm{C}$ dengan lama pengeringan 2 jam hasilnya adalah 6,38\%, dan lama pengeringan $3,4,5$, dan 6 jam masing-masing adalah 6,59\%; 6,77\%; 6,78\%; dan 6,77\%. Rerata kadar air konstan suhu $110^{\circ} \mathrm{C}$ pada sampel BR1 dan $\mathrm{KBr}$ tercapai dengan lama waktu pengeringan minimal 4 jam, yaitu masing-masing 10,08\% dan $6,77 \%$.

Pengeringan pada suhu $110^{\circ} \mathrm{C}$ selama 2 , 3, 4, 5, dan 6 jam masing-masing tercapai rerata kadar air jagung giling adalah 9,48\%; $10,29 \%$; 10,66\%; 10,66\%; dan 10,66\%. Pengeringan pada suhu $110^{\circ} \mathrm{C}$ selama $2,3,4$, 5 , dan 6 jam tercapai rerata kadar air pada bekatul masing-masing adalah 7,74\%; 8,34\%; 8,89\%; 8,90\%; dan 8,91\%, sedangkan kadar air BKK masing-masing adalah 10,26\%; $10,37 \%$; 10,85\%; 10,85\%; dan 10,86\%. Pengeringan pada BR1 dan $\mathrm{KBr}$ dengan suhu $110^{\circ} \mathrm{C}$ membutuhkan waktu minimal 4 jam untuk mencapai rerata kadar air konstan seperti pada jagung giling, bekatul, dan bungkil kedelai $(10,66 \% ; \quad 8,89 \%$; dan $10,85 \%)$. Pengeringan dengan suhu $110^{\circ} \mathrm{C}$ selama minimal 4 jam atau sampai tercapai kadar air konstan diperkuat dengan pendapat Winarno (2005) yang menyatakan penetapan kadar air dilakukan dengan mengeringkan bahan dalam oven dengan suhu $110^{\circ} \mathrm{C}$ selama 3 jam atau sampai berat konstan (kadar air konstan). Rerata kadar air konstan pada suhu $110^{\circ} \mathrm{C}$ untuk sampel $\mathrm{BR} 1, \mathrm{KBr}$, jagung giling, bekatul, dan BKK masing-masing adalah 10,08\%; 6,78\%; 10,66\%; 8,90\%; dan 10,86\% dengan standar deviasi kurang dari $1(\mathrm{SD}<1)$ sehingga akurasinya 99\%. Hal ini menunjukkan penyebaran nilai mendekati rerata persentase kadar air konstan.

\section{KESIMPULAN}

Hasil penelitian ini disimpulkan bahwa untuk menetapkan kadar air dengan metode oven pada bahan pakan dan pakan yang mempunyai kadar air simpan $(\leq 14 \%)$ membutuhkan waktu lama pengeringan optimum 6 jam pada suhu $105^{\circ} \mathrm{C}$ dan 4 jam pada suhu $110^{\circ} \mathrm{C}$.

\section{DAFTAR PUSTAKA}

Anggorodi. 2005. Ilmu Makanan Ternak Umum. PT Gramedia. Jakarta.

BSP (Bika Solusi Perdana). 2014. Istilah Verifikasi dan Validasi dalam ISO/IEC 17025.

http://www.bikasolusi.co.id/istilahverifikasi-dan-validasi-dalam-isoiec17025/. Diakses tanggal 15 Agustus 2018.

Fellow, P.J. 2001. Food Processing Technology, Principles and Practices. CRC Press. Boca Raton.

Keputusan Menteri Pendidikan Nasional Republik Indonesia No. 045/U/2002 tentang Kurikulum Inti Pendidikan Tinggi. Departemen Pendidikan Nasional. Jakarta.

Saenab, A., E.B. Laconi, Y. Retnani, dan M.S. Mas'ud. 2010. Evaluasi Kualitas Pelet Ransum Komplit yang Mengandung Produk Sampingan Udang. Jurnal Ilmu Ternak dan Veteriner. 15(1): 31-39.

Soelistyono, H.S. 1976. Ilmu Bahan Makanan Ternak. Fakultas Peternakan Universitas Diponegoro. Semarang.

Sudarmadji, S., Slamet, dan Bayu. 2007. Analisis Bahan Makanan dan Pertanian. Liberty. Yogyakarta.

Suyanto. 2011. Metodologi dan Aplikasi penelitian. Nuha Medika. Yogyakarta.

Tillman, D.A., H. Hartadi, S. Reksohadiprojo, S. Prawirokusumo, dan S. Lebdosoekojo. 1998. Ilmu Makanan Ternak Dasar. Gadjah Mada University Press. Yogyakarta.

Tim Laboratorium Ilmu dan Teknologi Pakan Fakultas Peternakan IPB. 2012. Pengetahuan Bahan Makanan Ternak. CV Nutri Sejahtera. Bogor.

Tim Pengampu Bahan Pangan Ternak Unggas. 2016. Buku Kerja Praktik Mahasiswa. Politeknik Negeri Jember. Jember.

Winarno, F.G. 2005. Kimia Pangan dan Gizi. PT Gramedia Pustaka Utama. Jakarta. 